\title{
The Potential Efficacy of Broussonetia kazinoki Stem Extract to Show Antioxidant Property or Suppress Collagenase Activity
}

\author{
Bora Kwon ${ }^{1 \#, ~ M i ~ H e e ~ K i m ", ~ I n ~ S u n ~ P a r k ~}{ }^{1}$, Young Moo Choo ${ }^{1}$, Kwang Sang Kim², Min Sook Kim², \\ Min Ji Kim², Hwa Jin Kim², Da In Choi ${ }^{2}$, Miyeon Park ${ }^{2}$, Moosung Kim³ ${ }^{3}$, Min Kyu Shin ${ }^{3}$, Jungno \\ Lee $^{4}$, Seung Il Jeong ${ }^{1}$, Kang Yeol $\mathrm{Yu}^{1}$ and Jiyoung Kim ${ }^{1 *}$ \\ ${ }^{1}$ Jeonju AgroBio-Materials Institute, Jeonju-si, Jeonbuk 54819, Korea
}

${ }^{2}$ Hisol Co., Ltd., Namwon-Si, Jeonbuk 55717, Korea

${ }^{3}$ MacroCare Tech, Ltd., Cheongju-Si, Chungbuk 28126, Korea

${ }^{4}$ Department of Bionanomaterials, Bio Campus of Korea Polytechnics, Korea

${ }^{\#}$ These authors contributed equally to this work

*Corresponding author: Jiyoung Kim, Jeonju Agro Bio Materials Institute, Korea

ARTICLE INFO
Received: w $^{-1}$ April 10, 2019
Published: April 24, 2019
Citation: Bora K, Mi Hee K, In Sun
P, Young Moo C, Jiyoung K, et al.
The Potential Efficacy of Brous-
sonetia kazinoki Stem Extract to
Show Antioxidant Property or Sup-
press Collagenase Activity. Biomed
J Sci \& Tech Res 17(3)-2019. BJSTR.
MS.ID.002998.

\section{ARTICLE INFO}

Received: April 10, 2019

MS.ID.002998.
ABSTRACT

In this study, Broussonetia kazinoki stem extract (BKSE) had potent antioxidant activity and inhibited collagenase, which breaks down collagen in skin, activity. These results suggest that BKSE has the potential to exhibit antioxidant activity and suppress collagenase activity in skin. Collagen is the main structural protein in the extracellular space in skin connective tissue. BKSE can help maintain skin's collagen content by eliminating reactive oxygen species and inhibiting collagenase activity. Through these activities, BKSE can be used as a cosmetic raw material to suppress skin wrinkles.

Keywords: Broussonetia Kazinoki; Antioxidant; Collagenase Inhibition; Skin

Abbrviations: BKSE: Broussonetia kazinoki Stem Extract; SOD: Superoxide Dismutase; HEK-293T: Human Kidney Epithelial Cells; MOTIE: Ministry of Trade, Industry \& Energy, KIAT: Korea Institute for Advancement of Technology

\section{Introduction}

Broussonetia kazinoki (Siebold) is a kind of tree belonging to the Rosaceae family. It grows mainly in the mountain side of the shore but has been cultivated many times in recent years. The bark is the material that makes the paper, and the fruit and stem are used as a medicinal material, and the young leaves are eaten [1-4]. According to the ancient Chinese medicine book, the leaves of $B$. kazinoki are effective in the treatment of edema, and the stems of B. kazinoki can be used for the treatment of symptoms such as rubella and poor urination. In this study, we report novel efficacy of $B$. kazinoki stem extract (BKSE) to show antioxidant property or inhibit collagenase activity. Antioxidants are a very important means of protecting the living body by eliminating the toxic effects of active oxygen [5]. If the living body cannot adequately remove active oxygen due to lack of antioxidants, various diseases and aging progress rapidly. Antioxidant enzymes naturally present in the human body include superoxide dismutase (SOD), glutathione and peroxidase [5]. First, we investigated whether BKSE displays a cytotoxic effect on human kidney epithelial cells (HEK-293T). Cytotoxic effect by BKSE on HEK-293T cells was not observed, suggesting that BKSE does not have a negative effect on human cells (Figure 1). The DPPH (1,1-diphenyl-2-picrylhydrazyl) radical scavenging assay provides an easy and rapid way to evaluate potential antioxidants. Our DPPH radical scavenging assay suggests that BKSE has an excellent effect on removing DPPH free radicals (Figure 2). Therefore, our results suggest that BKSE has excellent antioxidant activity. 


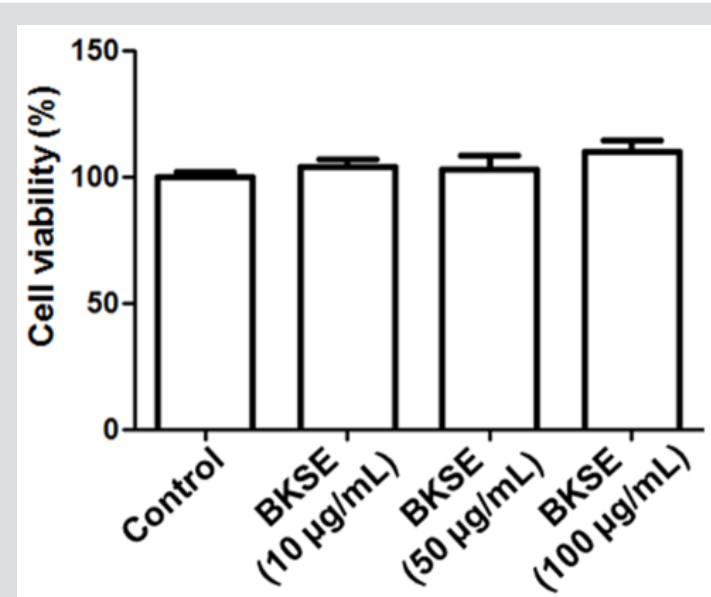

Figure 1: HEK-293T cells were treated with BKSE (0$100 \mu \mathrm{g} / \mathrm{mL}$ ), and cell viability at $24 \mathrm{~h}$ was determined using the MTS colorimetric assay. Error bars represent SD from three biological replicates.

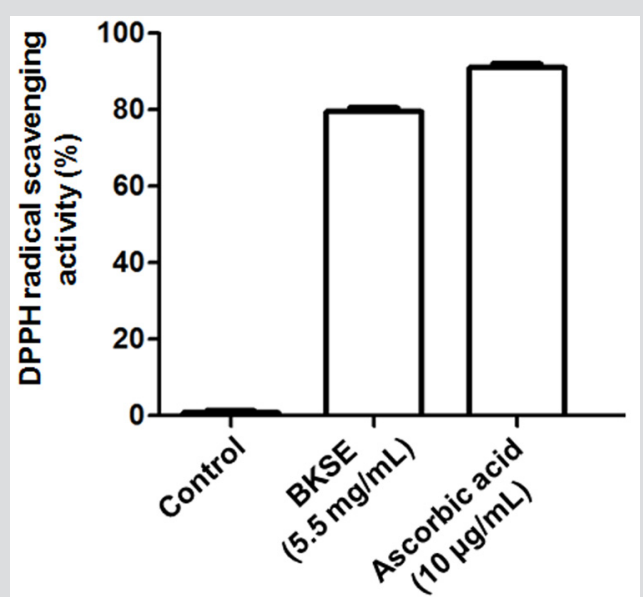

Figure 2: DPPH radical scavenging assay using BKSE $(5.5 \mathrm{mg} / \mathrm{mL})$. Ascorbic acid was used as a positive control. Error bars represent SD from three technical replicates.

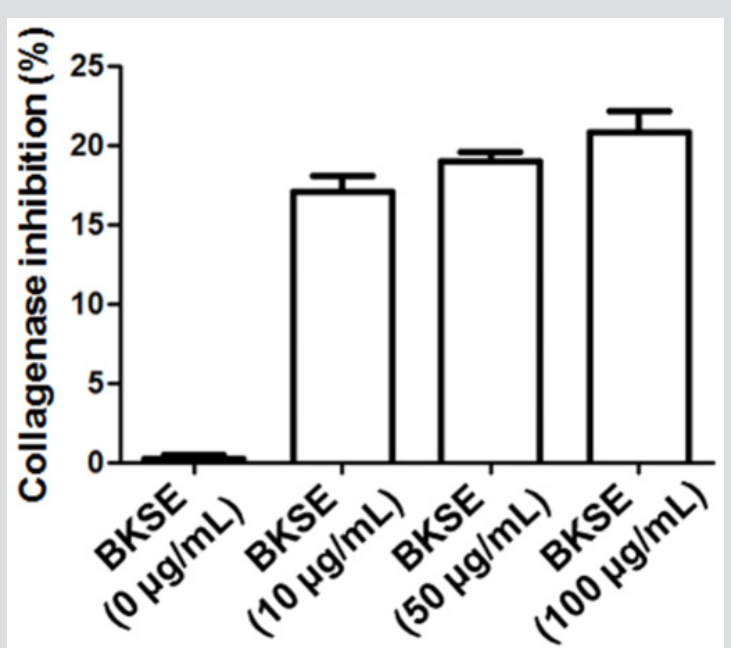

Figure 3: BKSE inhibits collagenase activity in vitro. Collagenase inhibition activity assay was performed using Enzchek collagenase assay kit following the manufacturer's instruction. Error bars represent SE from three technical replicates.
Collagenase is an enzyme of the matrix metalloproteinase family that breaks down collagen and destroys extracellular matrix [6]. Collagen is an abundant structural protein present in animals. Collagenase has a direct effect on skin elasticity and wrinkles through the breakdown of collagen that makes up the skin cell connective tissue. We investigated whether BKSE inhibits collagenase activity. The results showed that BKSE is able to effectively inhibit collagenase activity (Figure 3). BKSE can inhibit the activity of collagenase to properly maintain the collagen content of the skin, thereby adding the elasticity of the skin. Therefore, this work suggests that BKSE can be used as a natural product to prevent wrinkle formation in the skin. In conclusion, BKSE shows excellent antioxidant activity and inhibits collagenase activity. These results indicate that BKSE might be used a raw material for cosmetics to suppress skin wrinkles.

\section{Materials and Methods}

MTS (3-(4,5-dimethylthiazol-2-yl)-5-(3-carboxymethoxyphenyl)2-(4-sulfophenyl)-2H tetrazolium) assay in HEK-293T cells. The B. kazinoki stem was dried and extracted using EtOH (70\%) for 24 hours. The MTS assay was performed as described previously [7]. Briefly, the cells were seeded in a 96-well $(2 \times 104$ cells/well $)$ and treated with different doses of BKSE for $24 \mathrm{~h}$. After incubation, $20 \mu \mathrm{L}$ of the MTS working solution (2 mg/mL in PBS) was added to each well and incubated at $37^{\circ} \mathrm{C}$ for $4 \mathrm{~h}$. Absorbance at $490 \mathrm{~nm}$ was measured using a microplate reader (PerkinElmer) and cell viability was determined as the percentage of MTS reduction, assuming the absorbance of control cells as $100 \%$.

\section{DPPH Radical Scavenging Assay}

DPPH radical scavenging assay was performed as described previously with minor modifications [7]. Briefly, the reaction mixture contained $100 \mu \mathrm{L}$ of BKSE and $0.1 \mathrm{mM}$ DPPH solution. The mixture was incubated for $30 \mathrm{~min}$ at $37^{\circ} \mathrm{C}$, and then the activity was measured spectrophotometrically at $517 \mathrm{~nm}$. The blank was 100 $\%(v / v)$ ethanol. DPPH scavenging effect was calculated using the following equation:

DPPH scavenging effect $(\%)=\{(\mathrm{A} 0-\mathrm{A}) / \mathrm{A} 0\} \times 100$.

Where A0 is the absorbance of negative control $0.1 \mathrm{mM} \mathrm{DPPH}$ solution) and $\mathrm{A}$ is the absorbance in presence of BKSE.

\section{Collagenase Inhibition Activity Assay}

Collagenase inhibition activity assay was performed using EnzChek Collagenase Assay Kit (Molecular Probes) following the manufacturer's instruction.

\section{Acknowledgments}

This research was supported by the Ministry of Trade, Industry \& Energy (MOTIE), Korea Institute for Advancement of Technology (KIAT) through the Encouragement Program for The Industries of Economic Cooperation Region.

\section{Conflicts of Interest}

The authors report no conflicts of interest. 


\section{Ethical Approval}

This article does not contain any studies with human participants or animals performed by any of the authors.

\section{References}

1. Lee JK, Ha H, Lee HY, Park SJ, Jeong SL, et al. (2010) Inhibitory effects of heartwood extracts of Broussonetia kazinoki Sieb on the development of atopic dermatitis in NC/Nga mice. Biosci Biotechnol Biochem 74(9): 1802-1806

2. Kim HS, Lim J, Lee DY, Ryu JH, Lim IS (2015) Kazinol C from Broussonetia kazinoki activates AMP-activated protein kinase to induce antitumorigenic effects in HT-29 colon cancer cells. Oncol Rep 33(1): 223-229.

3. Ryu JH, Ahn H, Lee HJ (2003) Inhibition of nitric oxide production on LPS-activated macrophages by kazinol B from Broussonetia kazinoki. Fitoterapia 74(4): 350-354.

\section{ISSN: 2574-1241}

DOI: 10.26717/BJSTR.2019.17.002998

Jiyoung Kim. Biomed J Sci \& Tech Res

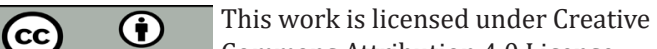

Submission Link: https://biomedres.us/submit-manuscript.php
4. Baek YS, Ryu YB, Curtis Long MJ, Ha TJ, Rengasamy R, et al. (2009) Tyrosinase inhibitory effects of 1,3-diphenylpropanes from Broussonetia kazinoki. Bioorg Med Chem 17(1): 35-41.

5. Lobo V, Patil A, Phatak A, Chandra N (2010) Free radicals, antioxidants and functional foods: Impact on human health. Pharmacogn Rev 4(8): 118-126.

6. Badalamente MA, Hurst LC (2018) Development of collagenase treatment for dupuytren disease. Hand Clin 34(3): 345-349.

7. Choi YJ, Park IS, Kim MH, Kwon B, Choo YM, et al. (2018) The medicinal mushroom Auricularia auricula-judae (Bull.) extract has antioxidant activity and promotes procollagen biosynthesis in HaCaT cells. Nat Prod Res.

$\begin{array}{ll}\text { BIOMEDICAL } & \text { Assets of Publishing with us } \\ \text { RESEARCHES } & \text { - Global archiving of articles } \\ & \text { - Immediate, unrestricted online access } \\ & \text { - Rigorous Peer Review Process } \\ \end{array}$

